\title{
Optimizing application rate of nitrogen, phosphorus and cattle manure in wheat production: An approach to determine optimum scenario using response-surface methodology
}

\author{
Mohsen Jahan $^{1^{*}}$, Mohammad Behzad Amiri² \\ ${ }^{1}$ Associate Prof. of Agroecology, Ferdowsi University of Mashhad, Faculty of Agriculture, P.O. Box 91775 - \\ 1163, Mashhad, Iran. ${ }^{2}$ Assistant Prof. of Agroecology, Dep. Plant Production Engineering, Gonabad University, \\ Khorasan Razavi, Iran. *Corresponding author: jahan@um.ac.ir
}

\begin{abstract}
Optimal application rates of inorganic nitrogen $(\mathrm{N})$, phosphorus $(\mathrm{P})$ and cattle manure were estimated using Response Surface Methodology (RSM). A Central Composite Design (CCD) was conducted at field level during 2012-13 and 2013-14 growing seasons. The applied levels of $\mathrm{N}$ were 0,150 and $300 \mathrm{~kg} \mathrm{~N}^{-1}$ in form of urea. The levels used for P fertilizer were 0,100 and $200 \mathrm{~kg} \mathrm{ha}^{-1}\left(\mathrm{P}_{2} \mathrm{O}_{5}\right)$ and for cattle manure were 0,15 and 30 $\mathrm{t} \mathrm{ha}^{-1}$. Both seed yield (SY), biological yield (BY) were measured at harvest time. $\mathrm{N}$ loss (NL) and Agronomic N Use Efficiency (ANUE) were calculated based on other measurements. Increasing N and P rates up to $200 \mathrm{~kg}$ $\mathrm{ha}^{-1}$ increased SY. Optimization of N, P and manure application amount was based on economic, environmental and eco-environmental scenarios. Under economic scenario, using $145.4 \mathrm{~kg} \mathrm{ha}^{-1} \mathrm{~N}, 200 \mathrm{~kg} \mathrm{ha}^{-1} \mathrm{P}$ and $18.4 \mathrm{t}$ $\mathrm{ha}^{-1}$ manure resulted in $6500 \mathrm{~kg} \mathrm{ha}^{-1} \mathrm{SY}$ with ANUE of 10.49. For environmental scenario, by $\mathrm{N}$ application of $21.2 \mathrm{~kg} \mathrm{ha}^{-1}$, no application of $\mathrm{P}$ and applying $16.3 \mathrm{t} \mathrm{ha}^{-1}$ manure, SY and ANUE of $3160 \mathrm{~kg} \mathrm{ha}^{-1}$ and 9.08 were obtained, respectively. Using eco-environmental scenario, by applying $144.7 \mathrm{~N}$ and $34.3 \mathrm{~kg} \mathrm{ha}^{-1} \mathrm{P}$, plus $30 \mathrm{t} \mathrm{ha}^{-1}$ manure, about $4031 \mathrm{~kg} \mathrm{ha}^{-1} \mathrm{SY}$ and a considerable high ANUE of 16.5 were recorded. The results of this study showed that the privilege of eco-environmental scenario compared to the other scenarios was mainly due to higher ANUE.
\end{abstract}

Keywords: ANUE, nitrogen losses, eco-environmental scenario, seed yield, central composite design 


\section{Introduction}

Higher required production of wheat has intensified consumption of agrochemicals that in turn have resulted in negative impacts on environment. Sustainable and sufficient food production is a necessity that simultaneously should consider social, economic and environmental aspects. The first step to achieve this goal is optimization and improvement of resources use efficiencies (Gliessman, 1998). It is reported that up to 50 percent of applied nitrogen would drift from agricultural systems as gaseous compounds and other types of activated nitrogen (Jarvis et al., 2011; Weligama et al., 2010). At the high level application of $\mathrm{P}$ (more than $200 \mathrm{~kg} \mathrm{ha}^{-1}$ ), up to $90 \%$ of phosphorous fertilizers would be fixed in soil together with metallic elements as insoluble forms which finally lead to further phosphorus pollution (Adesemoye et al., 2009). In many crops, low absorption efficiency of fertilizers, is the main reason of leaching, volatilization and diffusion of soluble chemical fertilizers easily released to soil and air (Akiyama et al., 2000). It has been reported that between 18-41 percent of applied nitrogen retain in soil after crop harvesting (Fageria, 2014). Nitrogen losses occur in various ways as ammonium volatilization in lime soils (10-70\%), denitrification (9-22\%) and leaching (14-40\%) (Doberman \& Cassman, 2004).

Wheat crop shows a strong positive correlation between productivity and NPK fertilizers (Hawkesford \& Barraclough, 2011; Osborne, 2007). On the other hand, applying organic fertilizers in integration with chemical ones could be an efficient management practice to reduce application rate of chemical fertilizers and subsequently reduce their negative impacts on environment. Moreover, improved nutrient balance in soil and plant, enhance crop productivity and yield stability in intensified cultivation. Synchrony between application time and crop nutrient demand, is an important factor, which reduce nitrogen losses (Gastal \& Lemaire, 2002). Thus integrated use of slow release organic fertilizers such as manure could reduce $\mathrm{N}$ losses during crops cultivation (Emilsson $e t$ $a l ., 2007)$. In arid and semi-arid regions, $\mathrm{N}$ deficiency occurs faster than other nutrients and usually is due to low level of soil organic matter. It seems necessary to design cropping systems with high nutrient uptake and utilization efficiencies (Fageria, 2014; Cassidy et al., 2013) considering global high demand for cereal in coming future. It is suggested to increase the mean efficiency of $\mathrm{N}$ utilization by $0.1-0.4 \%$ annually (Doberman \& Cassman, 2005). Improving $\mathrm{N}$ use efficiency, increases economic return and reduces the potential of environmental pollution (Fageria, 2014). To reach such goals, research priorities might be shifted from maximizing yield to developing methods for optimization of nutrients application.

Response Surface Methodology (RSM) was first introduced as optimization method for industrial use (Myers and Montgomery, 1995) however; this methodology could also be used in fertilizer optimization. Central Composite Design (CCD), which is the most popular RSM design, was implemented to design a series of tests with least number of experiments. This approach tries to investigate the effect of parameters involved (i.e. contact time, dosage, $\mathrm{pH}$, initial concentration) on responses in a cost- and time-effective way. The CCD makes it feasible to observe the possible interaction of the parameters and their influences used RSM methodology to optimize N, water and plant density in canola cultivation. reported that the application of $93.48 \mathrm{~kg} \mathrm{~N} \mathrm{ha}^{-1}$ based on eco-environmental scenario was an optimized $\mathrm{N}$ use, was able to reduce environmental hazards and produced acceptable onion yield. It has been claimed that oxalic acid and lactic acid are the major acids responsible for enhancing the $\mathrm{P}$ solubilization . 
This study was aimed to optimize the chemical and organic fertilizer use in winter wheat production and determine the best applicable scenario in Kashaf-rood watershed in northeast of Iran. It has also been studied the application trend of different N, P and cattle manure levels and their effects on wheat production. Furthermore, the effectiveness of manure compared to chemical fertilizer was studied based on NUE and wheat yield improvement.

\section{Material and Methods}

\subsection{Site description}

Field studies conducted during 2012-13 and 2013-14 growing seasons at the Research Station of Agriculture Faculty, Ferdowsi University of Mashhad, Iran (latitude: $36^{\circ} 15 \notin \mathrm{N}$; longitude: $59^{\circ} 28 \notin \mathrm{E}$; elevation: $985 \mathrm{~m}$ above sea level). Experiment station was located in Kashaf-rood watershed in northeast of the country in a semi-arid region with mean annual precipitation of $252 \mathrm{~mm}$ and temperature of $15^{\circ} \mathrm{C}$.
Soil samples were taken from $0-15$ and $15-30 \mathrm{~cm}$ depths and analyzed for some physiochemical properties before beginning the experiment (Table 1). To determine soil nitrogen content, soil sampling was repeated at the end of growing season.

\subsection{Experimental design}

CCD (sometimes called Box-Behnken design) with two replicates was used for fitting response surface to experimental data (Tawfik et al., 2017). Two years data where subjected to combined analysis after ensuring uniformity of the error mean squares. The results of combined analysis indicated that year $\times$ treatment interaction was not significant $(P>0.05)$, therefore the two years data were joined before exposing to response surface analysis.

The experimental factors were the combination of different amounts of nitrogen, phosphorus and cattle manure. The total number of experimental runs for a 3 -factor CCD is 15 including 12 factorial points and 3 replications for center points.

Table 1. Soil properties of the experimental field (mean of two years).

\begin{tabular}{lcc}
\hline & \multicolumn{2}{c}{ Soil depth $(\mathrm{cm})$} \\
\cline { 2 - 3 } Soil properties & $0-15$ & $15-30$ \\
\hline Total N (\%) & 0.078 & 0.065 \\
Available P (ppm) & 19 & 15 \\
Available K (ppm) & 380 & 372 \\
$\mathrm{C} / \mathrm{N}$ & 12.8 & 12.3 \\
$\mathrm{pH}($ saturation extract) & 7.7 & 7.5 \\
EC $\left(\mathrm{dS} \mathrm{m} \mathrm{m}^{-1}\right)$ & 1.3 & 1.3 \\
Water storage capacity $(\%)$ & 22.3 & 20 \\
Bulk density $\left(\mathrm{g} \mathrm{cm}^{-3}\right)$ & 1.34 & 1.41 \\
Texture grade & Loamy-silt & Loamy-silt \\
\hline
\end{tabular}


By conducting $\mathrm{CCD}$, it is possible to obtain all information from the least operational practices due to distribution of experimental points through treatments confined. The design points were defined based on the low and high levels of $\mathrm{N}\left(0,300 \mathrm{~kg} \mathrm{ha}^{-1}\right), \mathrm{P}(0,200$ $\left.\mathrm{kg} \mathrm{ha}^{-1}\right)$ and manure $\left(0,30 \mathrm{tha}^{-1}\right)$ (Table 2). The N, P and $\mathrm{K}$ content of manure were determined as $1.18 \%$, $0.29 \%$ and $1.04 \%$, respectively. The high and low levels of manure were determined based on nutrient content and local recommendations.

Table 2. Actual and coded values of expeimental factors for CCD.

\begin{tabular}{|c|c|c|c|c|c|c|}
\hline \multirow[b]{2}{*}{ Runs } & \multicolumn{3}{|c|}{ Treatment values* } & \multicolumn{3}{|c|}{ Coefficients } \\
\hline & $\begin{array}{r}\text { Nitrogen } \\
\left(\mathrm{kg} \mathrm{ha}^{-1}\right)\end{array}$ & $\begin{array}{l}\text { Phosphorus } \\
\left(\mathrm{kg} \mathrm{ha}^{-1}\right)\end{array}$ & $\begin{array}{c}\text { Manure } \\
\left(\mathrm{t} \mathrm{ha}^{-1}\right)\end{array}$ & $\begin{array}{c}\text { Nitrogen } \\
\left(\mathrm{X}_{1}\right)\end{array}$ & $\begin{array}{c}\text { Phosphorus } \\
\left(\mathrm{X}_{2}\right)\end{array}$ & $\begin{array}{c}\text { Manure } \\
\left(\mathrm{X}_{3}\right)\end{array}$ \\
\hline 1 & 300 & 0 & 15 & +1 & -1 & 0 \\
\hline 2 & 150 & 0 & 15 & 0 & -1 & 0 \\
\hline 3 & 300 & 100 & 30 & +1 & 0 & +1 \\
\hline 4 & 300 & 100 & 0 & +1 & 0 & -1 \\
\hline 5 & 0 & 100 & 30 & -1 & 0 & +1 \\
\hline 6 & 150 & 100 & 15 & 0 & 0 & 0 \\
\hline 7 & 150 & 0 & 30 & 0 & -1 & +1 \\
\hline 8 & 0 & 100 & 0 & -1 & 0 & -1 \\
\hline 9 & 150 & 0 & 0 & 0 & -1 & -1 \\
\hline 10 & 150 & 200 & 0 & 0 & +1 & -1 \\
\hline 11 & 150 & 200 & 30 & 0 & +1 & +1 \\
\hline 12 & 150 & 100 & 15 & 0 & 0 & 0 \\
\hline 13 & 0 & 200 & 15 & -1 & +1 & 0 \\
\hline 14 & 300 & 200 & 15 & +1 & +1 & 0 \\
\hline 15 & 150 & 100 & 15 & 0 & 0 & 0 \\
\hline
\end{tabular}

A normality test was already performed and transformation was also performed for numerical data where needed. To ensure uniformity of treatment variances, the Bartlett's test was used. Since there was no statistical difference between both years of data, the mean value of each trait was reported. Data analysis and graph plotting were performed using Minitab ${ }^{\circledR}$ Statistical Software Ver. 16.1.1, and Microsoft Excel Ver. 14

\subsection{Crop management}

Plots of $3 \times 4 \mathrm{~m}$ with a distance of 1 meter between, to avoid nutrients mixing due to irrigation, were prepared. Each plot consists of 6 rows that were arranged to sow wheat seeds on double side of rows. Manure was well mixed with soil one month before planting. The first $\mathrm{N}$ installment and the whole $\mathrm{P}$ amount were applied at sowing. The sowing dates (October 10, 2013-14) were the same for both years of experiment. Plots were immediately irrigated after sowing and after that irrigation continued at 10-day intervals. An eco-climate appropriate cultivar (Gascogne) was employed in this study. The plant density was 350 plants per square meter. Weeds were controlled two times during the growth period by hand. No agrochemical was used during soil cultivation, planting and growing season. 


\subsection{Measurements}

Each plot was partitioned into two sections, one for seed yield and its components and the second section used for destructive time series sampling during the crop growth season. Before the final harvest, 5 plants from each plot were randomly selected and the number of fertile tillers was recorded. Seed yield was determined from $4 \mathrm{~m}^{2}$ of each plot which was kept untouched, considering marginal effect. The air dried plants were weighed and biological yield (dry matter yield), seed yield and harvest index were also measured.

The $\mathrm{N}$ contents in plant tissue were measured using AOAC Official Method by a Kajehldal Semi Automated Distillation Unit (Horwitz \& Latimer, 2005). The total $\mathrm{N}$ was determined for each soil plot (AOAC official method 968.06 (4.2.04)). Nitrogen loss was calculated using Equation 1 (Jarvis et al., 2011):

$$
N_{\text {loss }}=N_{\text {initial }}+N_{\text {fertilizer }}-\left(N_{\text {plant }}+N_{\text {soil }}\right)
$$

Eq.1

Where, $\mathrm{N}_{\text {loss }}$ : nitrogen loss $\left(\mathrm{kg} \mathrm{m}^{-2}\right), \mathrm{N}_{\text {initial: }}$ soil available nitrogen content at the early season $\left(\mathrm{kg} \mathrm{m}^{-2}\right)$ which was calculated by: $\mathrm{N}_{\text {Total End }} \times 0.03$

$0.03=$ availability coefficient of total $\mathrm{N}$ in soil (as mineral for crop use) (Fageria, 2014).

$\mathrm{N}_{\text {fertilizer }}$ : applied nitrogen $\left(\mathrm{kg} \mathrm{m}^{-2}\right), \mathrm{N}_{\text {plant }}$ : plant nitrogen content at the end of season, and $\mathrm{N}_{\text {soil }}$ : the available nitrogen content in soil after final harvest $\left(\mathrm{kg} \mathrm{m}^{-2}\right)$ which was calculated as:

$\mathrm{N}_{\text {Total End }} \times 0.03$.

Agronomical nitrogen use efficiency (ANUE, $\mathrm{kg}$ Grain/kg $\mathrm{N}_{\text {fertilizer }}$ ) was calculated using Equation 2 (Rathke et al., 2006):

$$
A N U E=\frac{Y_{\text {Grain }}}{N_{\text {initial }}+N_{\text {fertilizer }}}
$$

$\mathrm{Y}_{\text {Grain }}$ : seed yield $\left(\mathrm{kg} \mathrm{m}^{-2}\right)$

To determine relative water content (RWC) of leaves, the samples were prepared between 9:00 to 10:00 AM at flowering stage. The samples were submerged in distilled water for 6 hours and then turgor weight was measured and their dry weight were also recorded in after drying samples in $75^{\circ} \mathrm{C}$ in oven. Finally RWC was calculated using Equation 3 (Kramer, 1988):

$$
R W C=\frac{(F W-D W)}{(T W-D W)}
$$

\subsection{Statistical analysis}

Response of measured variables (y) to experimental factors $(\mathrm{X})$ was estimated using second order polynomials including the interaction (Equation 4):

$$
y=\beta_{0}+\sum_{i=1}^{m} \beta_{i} X_{i}+\sum_{i<j}^{m} \beta_{i j} X_{i} X_{j}+\sum_{i=1}^{m} \beta_{i i} X_{i}^{2} \quad \text { Eq. } 4
$$

Where $b_{0}$ is constant and $b_{i}, b_{i j}$ and $b_{i i}$ are coefficients for linear, interaction and quadratic terms, respectively.

The result was a second order polynomial which describes the estimated of response (yield) as a function of inputs variables. Finally, after optimizing the resulted function and eliminating the low effect terms using statistical tests and criteria such as, $\mathrm{F}$ test, lack of fit test, coefficient of determination $\left(\mathrm{R}^{2}\right)$, a final function was calculated to predict yield and other expected variables as below (Equation 5): 
$Y=a_{0}+a_{1} X_{1}+a_{2} X_{2}+a_{3} X_{3}+a_{4} X_{1}^{2}+a_{5} X_{2}^{2}+a_{6} X_{3}^{2}+a_{7} X_{1} X_{2}+a_{8} X_{1} X_{3}+a_{9} X_{2} X_{3}$

Eq.5

In this function, $\mathrm{Y}$ is dependent variable, $\mathrm{X}_{1}$ is $\mathrm{N}$ fertilizer, $\mathrm{X}_{2}$ is $\mathrm{P}$ fertilizer, $\mathrm{X}_{3}$ is manure, and $\mathrm{a}_{0}$ to $\mathrm{a}_{9}$ are coefficients. The equation is only functional in the defined range of input variables and would not predict the values out of the range.

The optimized rates of $\mathrm{N}, \mathrm{P}$ and manure determined three scenarios including: economic, environmental and eco-environmental, in which seed yield, $\mathrm{N}$ loss, NUE and $\mathrm{N}$ loss were the main determining factors, respectively.

Response-surface methodology was used to obtain the optimized levels. Finally, the fitted values compared to observed ones and validity of regression models were evaluated by Root Mean Square Error (RMSE) (Equation 6) and 1:1 regression line.

$$
\operatorname{RMSE}(\%)=\frac{100}{\bar{O}} \times \sqrt{\frac{\sum_{i=1}^{n}\left(P_{i}-O_{i}\right)}{n}} \quad \text { Eq.6 }
$$

The RMSE percentage states the different between predicted versus observed values. When RMSE $<10 \%$, prediction power of the used model is excellent, if $\mathrm{RMSE}<20 \%$, prediction power of model is good, if $\mathrm{RMSE}<30 \%$, it is considered as a poor prediction (Myers \& Montgomery, 1995).

\section{Results}

The results for analysis of variance of the full quadratic regression for dependent variables have been presented in Table 3. The dependent variables were: seed yield, biological yield, fertile tiller numbers, RWCL, N loss and NUE. The seed yield linear effects for $\mathrm{N}$ and $\mathrm{P}$ were significant at $5 \%$, and $1 \%$ probability level, respectively (data not shown).

Table 3. Regression coefficients of the fitted model.

\begin{tabular}{ccccccc}
$Y=a_{0}+a_{1} X_{1}+a_{2} X_{2}+a_{3} X_{3}+a_{4} X_{1}{ }^{2}+a_{5} X_{2}{ }^{2}+a_{6} X_{3}{ }^{2}+a_{7} X_{1} X_{2}+a_{8} X_{1} X_{3}+a_{9} X_{2} X_{3}$ \\
\hline & \multicolumn{7}{c}{ Response Variables } \\
\cline { 2 - 7 } Coefficient & $\begin{array}{c}\text { Seed } \\
\text { Yield }\end{array}$ & $\begin{array}{c}\text { Biological } \\
\text { Yield }\end{array}$ & $\begin{array}{c}\text { Fertile Tiller } \\
\text { numbers }\end{array}$ & $\begin{array}{c}\text { Relative } \\
\text { Water } \\
\text { Content }\end{array}$ & $\begin{array}{c}\text { Nitrogen } \\
\text { Losses }\end{array}$ & $\begin{array}{c}\text { Agronomical } \\
\text { Nitrogen } \\
\text { Use } \\
\text { Efficiency }\end{array}$ \\
\hline $\mathbf{a}$ & 2.939 & 15.11 & 2.863 & 78.97 & 65.5 & 12.64 \\
$\mathbf{a} 1$ & 0.03063 & -0.0155 & -0.00852 & -0.0258 & -0.136 & 0.0008 \\
$\mathbf{a} 2$ & -0.01522 & 0.0077 & -0.00836 & -0.0821 & 0.640 & 0.0606 \\
$\mathbf{a 3}$ & -0.0108 & 0.410 & 0.0203 & -0.496 & -11.36 & -0.424 \\
$\mathbf{a} 4$ & -0.000071 & -0.000006 & 0.000023 & 0.000146 & 0.00298 & 0.000148 \\
$\mathbf{a} 5$ & 0.000118 & -0.000094 & 0.000069 & 0.000274 & -0.00306 & -0.000326 \\
$\mathbf{a} 6$ & -0.00078 & -0.01059 & -0.000067 & 0.00866 & 0.349 & 0.01252 \\
$\mathbf{a} 7$ & -0.000045 & 0.000128 & 0.000023 & -0.000247 & -0.00073 & 0.000019 \\
$\mathbf{a}$ & -0.000042 & 0.000117 & 0.000067 & 0.000297 & 0.00106 & 0.000604 \\
$\mathbf{a 9}$ & 0.000229 & -0.001454 & -0.000333 & 0.00220 & 0.0151 & 0.000577 \\
$\mathbf{R}^{2}$ & 92.06 & 83.08 & 98.24 & 82.02 & 92.86 & 95.31 \\
\hline
\end{tabular}

$\mathrm{X}_{1}, \mathrm{X}_{2}$ and $\mathrm{X}_{3}$ indicates independent variables: nitrogen fertilizer, phosphorus fertilizer and manure, respectively. 
The second order effect was also significant for $\mathrm{N}$ $\times \mathrm{N}$ and $\mathrm{P} \times \mathrm{P}$ on seed yield $(\mathrm{P} \leq 0.01)$, fertile tiller numbers $(\mathrm{P} \leq 0.01)$ and NUE $(\mathrm{P} \leq 0.05)$. However, the interaction of $\mathrm{N} \times \mathrm{P} \times$ manure was significant only for the number of fertile tiller ( $\mathrm{P} \leq 0.01)$. The lack of fit of the regression model was not significant for the all studied traits .The regression coefficients of the fitted models for the studied traits have been presented in Table 3. The high coefficient of determination is indicated that the variances of the dependent variables were properly described by the full quadratic model used for response surface analysis (Table 3).

\subsection{Seed Yield}

The low RMSE indicated a good prediction ability of the model. Moreover, there was no significant differ ence between slope and intercept of regression line compared to the $1: 1$ line $\left(\mathrm{RMSE}=7.34 ; \mathrm{R}^{2}=0.92\right)$. The lowest SY (2350 $\left.\mathrm{kg} \mathrm{ha}^{-1}\right)$ obtained from the application of $0 \mathrm{~kg} \mathrm{ha}^{-1} \mathrm{~N}, 100 \mathrm{~kg} \mathrm{ha}^{-1} \mathrm{P}$ and $30 \mathrm{t} \mathrm{ha}^{-1}$ manure.

There was no significant $\mathrm{N} \times \mathrm{P}$ interaction effect on the SY. At any level of $\mathrm{P}$ fertilizer, SY response to $\mathrm{N}$ showed a quadratic trend with maximum yield achieved at $150 \mathrm{~kg} \mathrm{~N} \mathrm{ha}^{-1}$. However, the highest response of seed yield to $\mathrm{P}$ fertilizer was obtained at the highest level $\left(200 \mathrm{~kg} \mathrm{P} \mathrm{ha}^{-1}\right)$ and as a result the maximum SY was observed by application of 150 and $200 \mathrm{~kg} \mathrm{ha}^{-1} \mathrm{~N}$ and $\mathrm{P}$, respectively, while applied manure was $15 \mathrm{t} \mathrm{ha}^{-1}$ (Figure 1). At any level of $\mathrm{N}$, seed yield response was highest at high level of $\mathrm{P}$ $\left(200 \mathrm{~kg} \mathrm{ha}^{-1}\right)$. At high level application of N (300 kg $\mathrm{ha}^{-1}$ ), seed yield decreased at any P levels (Figure 3).

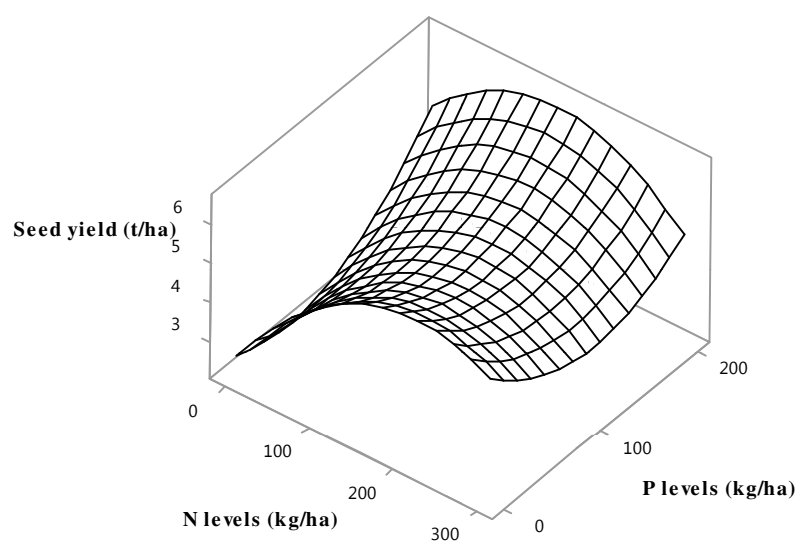

Figure 1. Response surface of wheat seed yield in different nitrogen and phosphorus fertilization at the constant level of $15 \mathrm{t} \mathrm{ha}^{-1}$ of manure. 


\subsection{Biological Yield}

Interaction effect of $\mathrm{P} \times \mathrm{M}$ was significant $(\mathrm{P} \leq 0.05)$ for BY (data not shown). At the high level of P fertilization $\left(200 \mathrm{~kg} \mathrm{ha}^{-1}\right)$, BY response to manure followed a diminishing return and decreased when applied manure levels were above $15 \mathrm{tha}^{-1}$. At no application of $\mathrm{P}$, the highest $\mathrm{BY}$ was obtained when the maximum manure level (30 t ha-1) was applied (Figure 2).

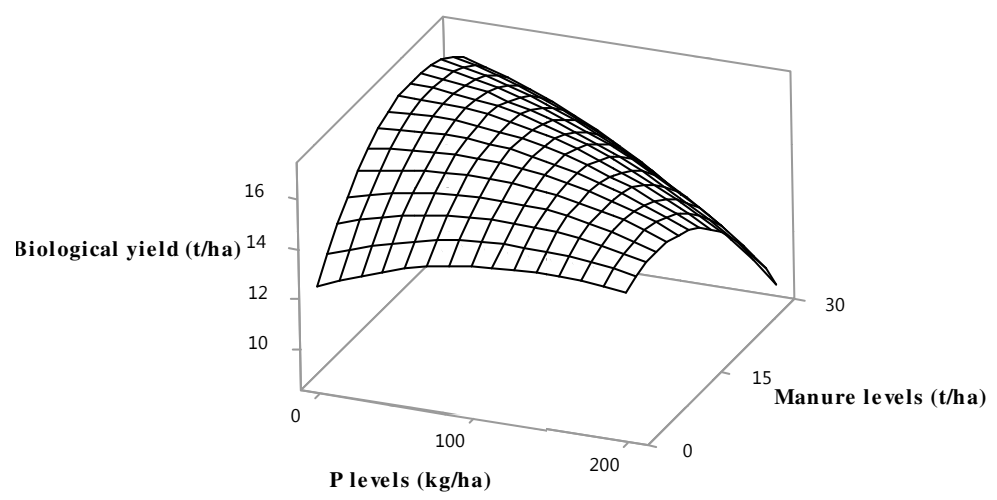

Figure 2. Response surface for biological yield in different phosphorus and manure fertilization at the constant level of $150 \mathrm{~kg} \mathrm{ha}^{-1}$ of nitrogen.

\subsection{Fertile tiller numbers}

Increasing the application of both $\mathrm{N}$ and $\mathrm{P}$, resulted in increased fertile tiller number per plant (not shown). The positive effect of $\mathrm{N}$ on plant growth only happens when adequate amounts of the other nutrients is available.

\subsection{Relative Water Content (RWC)}

RWC of leaves was positively related to the manure level, however, RWC negatively responded to the $\mathrm{P}$ application rate (not shown). RWC was dropped below $60 \%$ at the $\mathrm{P}$ rates higher than $200 \mathrm{~kg} \mathrm{ha}^{-1}$ but this response was moderated by increasing manure application. Apparently, with increasing $\mathrm{P}$ application a higher leaf expansion was taken place which was in turn led to the lower RWC. However, positive effects of manure on soil water retention is provided enough amount of water for sustaining leaf growth while keeping RWC at optimized level.

\subsection{Nitrogen loss}

Nitrogen loss (NL) positively responded to $\mathrm{N}$ application rate and manure level as well (Figure 3). The highest NL was achieved when $\mathrm{N}$-fertilizer and manure were applied at the maximum levels. 


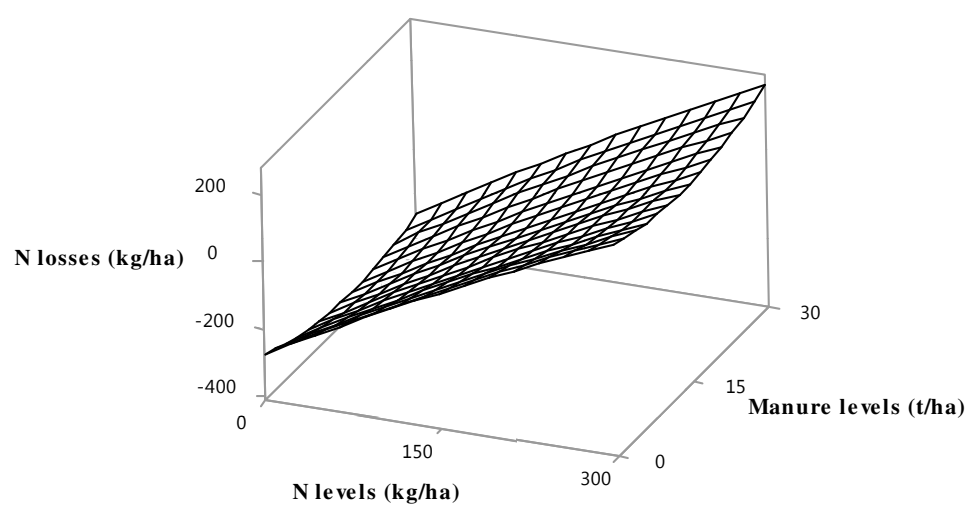

Figure 3. Response surface for nitrogen losses of different nitrogen and manure fertilization levels at constant level of $100 \mathrm{~kg} \mathrm{ha}^{-1}$ of phosphorus.

\subsection{Agronomical Nitrogen Use Efficiency (ANUE)}

ANUE decreased as a result of increasing in nitrogen and phosphorus application levels, although this increasing slope was higher at the mid level of $\mathrm{P}$ than of the low and the high levels (Figure 4).

The low RMSE $\left(8.51 ; R^{2}=0.92\right)$ for regression line of the fitted versus observed values for NUE indicated the goodness of fit of the model. Moreover, no significant difference was observed between regression line slope and intercept compared to the slope and intercept of 1:1 line (not shown).

RMSE values for response variables $(6.35,8.98$ for BY and NL, respectively) showed goodness of fit of the related models (data not shown), moreover, coefficients of determination in respected models (0.92; $0.81 ; 0.92$ and 0.92 for SY; BY; NL and ANUE, respectively) were confirmed the goodness of fit of the models.

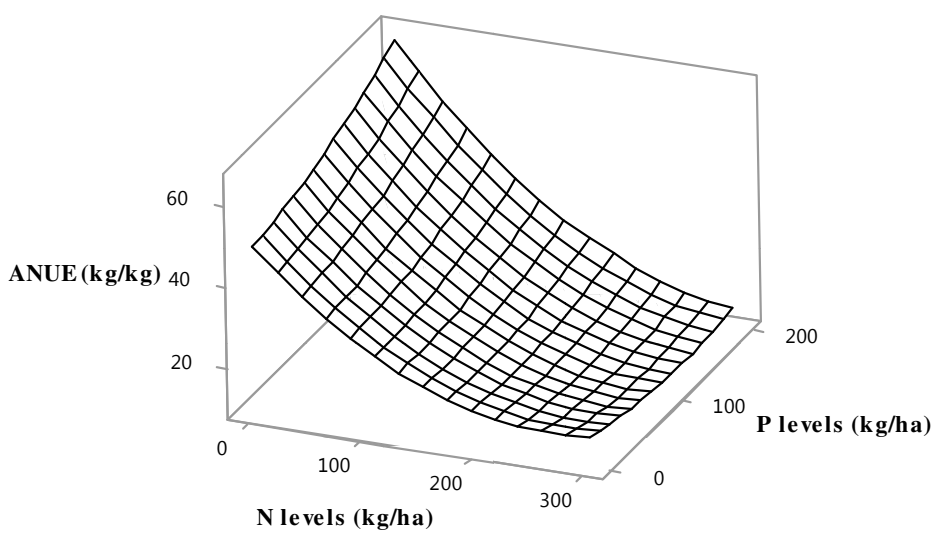

Figure 4. Response surface for agronomical nitrogen use efficiency of different nitrogen and phosphorus fertilization levels at constant level of $15 \mathrm{tha}^{-1}$ of manure. 


\subsection{Resource Optimization}

Optimization of nitrogen, phosphorus and manure fertilization were conducted according to the three scenarios of economic, environmental and eco-environmental. Under economic scenario, wheat seed yield was considered as the main determining factor for resource optimization. The result showed that application of $145.4 \mathrm{~kg} \mathrm{ha}^{-1} \mathrm{~N}, 200 \mathrm{~kg} \mathrm{ha}^{-1} \mathrm{P}$ and 18.4 $\mathrm{t} \mathrm{ha} \mathrm{a}^{-1}$ manure, could achieve a seed yield of about $6500 \mathrm{~kg} \mathrm{ha}^{-1}$ and a biological yield around $13130 \mathrm{~kg}$ ha-1 (Table 4).

Table 4. Optimized values of nitrogen, phosphorus fertilizers and manure application for reaching the dependent variables based on evaluated scenarios.

\begin{tabular}{|c|c|c|c|c|c|c|c|c|c|}
\hline \multirow[b]{2}{*}{ Scenarios } & \multicolumn{3}{|c|}{ Independent Variables (X) } & \multicolumn{6}{|c|}{ Dependent Variable (Y) } \\
\hline & $\begin{array}{l}\text { Nitrogen } \\
\left(\mathrm{kg} \mathrm{ha}^{-1}\right)\end{array}$ & $\begin{array}{l}\text { Phosphorus } \\
\left(\mathrm{kg} \mathrm{ha}^{-1}\right)\end{array}$ & $\begin{array}{c}\text { Manure } \\
\left(\mathrm{t} \mathrm{ha}^{-1}\right)\end{array}$ & $\begin{array}{l}\text { Seed } \\
\text { Yield } \\
\mathrm{kg}) \\
\left(\mathrm{ha}^{-1}\right.\end{array}$ & $\begin{array}{l}\text { Biological } \\
\text { Yield (kg } \\
\text { ha }^{-1} \text { ) }\end{array}$ & $\begin{array}{c}\text { Fertile } \\
\text { Tiller } \\
\text { Numbers }\end{array}$ & $\begin{array}{l}\text { Relative } \\
\text { Water } \\
\text { Content } \\
(\%)\end{array}$ & $\begin{array}{l}\text { Nitrogen } \\
\text { Losses } \\
\left(\mathrm{kg} \mathrm{ha}^{-1}\right)\end{array}$ & $\begin{array}{l}\text { Agronomical } \\
\text { Nitrogen } \\
\text { Use } \\
\text { Efficiency } \\
\text { (kg DM/ } \\
\text { kg N) }\end{array}$ \\
\hline Economic & 145.45 & 200 & 18.48 & 6500 & 13130 & 3.16 & 68.38 & 61.04 & 10.49 \\
\hline Environmental & 21.21 & 0 & 16.36 & 3160 & 11692 & 3.03 & 72.79 & 0 & 9.08 \\
\hline $\begin{array}{l}\text { Eco- } \\
\text { Environmental }\end{array}$ & 144.73 & 34.3 & 30 & 4031 & 15311 & 2.51 & 71.04 & 0 & 16.50 \\
\hline
\end{tabular}

Under eco-environmental scenario, the determining factor for optimizing resource was considered as NL. The main objective of this scenario was reduction of environmental hazards resulted from high rates application of N, P and possibly manure, so, the economic yield had less importance. According to this scenario, $\mathrm{N}$ application by $21.2 \mathrm{~kg} \mathrm{ha}^{-1}$ with no application of $\mathrm{P}$, plus $16.4 \mathrm{t} \mathrm{ha}^{-1}$ of manure, minimized the $\mathrm{NL}(0 \mathrm{~kg}$ $\left.\mathrm{ha}^{-1}\right)$. Considering the optimized amount of resource use in this scenario, seed yield, biological yield and ANUE were estimated about $3160 \mathrm{~kg} \mathrm{ha}^{-1}, 11692 \mathrm{~kg}$ $\mathrm{ha}^{-1}$ and $9.3 \mathrm{~kg} \mathrm{DM} / \mathrm{kg} \mathrm{N}$, respectively (Table 4).

Under environmental scenario, the main determining factors for optimizing resource, were ANUE, NL and seed yield. Application of 144.7 and $34.3 \mathrm{~kg} \mathrm{ha}^{-1}$ of $\mathrm{N}$ and $\mathrm{P}$, and $30 \mathrm{tha}^{-1}$ of manure resulted in the seed yield about 4031 and the biological yield of $15311 \mathrm{~kg}$ $\mathrm{ha}^{-1}$, which showed $36 \%$ increase of ANUE compared to the economic scenario (16.50 vs. 10.49).

\section{Discussion}

Increased seed yield by higher levels application of fertilizers in the present study is in agreement with other studies. Osborne (2007) reported a positive and strong correlation between available $\mathrm{N}$ in soil and spring wheat seed yield. Seguel et al. (2016) reported the plant growth in acidic soil is limited by low levels of available $\mathrm{P}$ and the high presence of phytotoxic aluminum $\left(\mathrm{Al}^{+}\right)$, which causes deleterious effect on plant physiology. They also suggested that wheat shoot dry weight, root dry weight and root colonization were influenced 
by wheat genotype/growth stages interaction and arbuscular mycorrhiza spores and P-ase activity were affected by wheat cultivar. Moraghebi et al. (2011) reported that increasing of $\mathrm{N}$ levels from 0 to 100 $\mathrm{kg} \mathrm{ha}^{-1}$ resulted in higher seed yield, protein percentage and biomass of wheat crop. Hatfield and Prueger (2004) reported that $\mathrm{N}$ fertilizer increased the yield of wheat seed through increasing seed numbers in spike and 1000 seeds weight. Mahmood et al. (2017) found a significant and positive correlation $\left(\mathrm{R}^{2}=0.52,0.91\right.$ and 0.55 ) among maize grain yield and available N, $\mathrm{P}$ and $\mathrm{K}$ content, in soil.

Higher levels of manure in soil usually lead to low $\mathrm{pH}$ (Mahmood et al., 2017). On the other hand, P availability is highly dependent on soil $\mathrm{pH}$ (Mengel and Kirkby, 2001). It is widely accepted that the maximum $\mathrm{P}$ availability in the soil come through in $\mathrm{pH}$ range of 6.5-7.5 which meets the optimal needs of many plants. The soil temperature, $\mathrm{CEC}$, and $\mathrm{pH}$ determine the availability of nutrients in the soil. Since $\mathrm{pH}$ levels control many bio-chemical processes that take place in the soil- specifically, plant nutrient availability- it is vital to maintain proper levels for plants to reach their full yield potential.

It could be explained that at high application rate of manure (30 $\left.\mathrm{t} \mathrm{ha}^{-1}\right)$, BY decreased at highest $\mathrm{P}$ fertilizer level due to $\mathrm{pH}$ limitation on $\mathrm{P}$ availability. Shah et al. (2016) reported increased dry matter of maize by application of manure. Organic matters, including cattle manure improve physiochemical properties of the soil mainly through buffering the $\mathrm{pH}$. Hussain et al. (2016) reported the $\mathrm{P}$ application had significant effect on dry matter and other yield components of wheat. Sandana and Pinochet (2016) reported that there were differences between wheat, pea and lupin regarding their sensitivity to $\mathrm{P}$ deficiency and the strategies that these species developed to acquire $\mathrm{P}$ from soil. They also suggested considering these dif- ferences could help improve fertilizer management strategies and optimize soil P use.

In present study, the positive effect of nitrogen on increasing fertile tiller numbers was clearly revealed at mid and high levels applications of phosphorus, but at zero application of phosphorus, no effect of $\mathrm{N}$ was observed. This was probably due to the limited effect of nitrogen in absence of phosphorus. The same result for $\mathrm{N} \times \mathrm{P}$ interaction was previously obtained for seed yield (Figure 1). N contributes in increased cell division, leaf area and its duration, increased tiller numbers and survival which eventually results the improvement of photosynthesis capacity and dry matter production (Davis et al., 2002). Schlemmer et al. (2005) reported that $\mathrm{N}$ deficiency caused reduction of water potential and increased the amount of abscisic acid in leaves, thus play an important role in senescence process. They also reported that nitrogen increased RWC and plants with more water content, contained more chlorophyll. Temperature of root region could affect nitrate absorption. Since organic matter such as cattle manure could affect the soil water holding capacity, thus, it could affect retaining and nutrients uptake (nitrogen in particular) too (Sparling et al., 2006; Kuepper, 2003). Increasing of NL by using high $\mathrm{N}$-rates could be due to the lower N-absorption efficiency that was reported as almost $30-40 \%$ in study region (Rathke et al., 2006). Higher soil water content due to manure application may negatively affect NL as a result of more N-leaching compared to the dry soils. Martinez-Lagos et al. (2015) reported that the slurry treated soil had greater net potential $\mathrm{N}$ mineralization than urea, which in turn results in lower rates of gross $\mathrm{N}$ immobilization and loss in time. They also suggested that for $\mathrm{N}$ fertilization amount determination, must consider the $\mathrm{N}$ which can be supplied by the soil mineralization in order to reduce $\mathrm{N}$ losses from the soil surface through different pathways particularly by $\mathrm{NH} 3$ pathway. The results showed that to 
avoid N-losses, the rate of nitrogen application should be recommended according to the applied manure. It is well known that ANUE decreases with the increment of $\mathrm{N}$ availability, (Dordas, 2011). Marino et al. (2004) reported that wheat NUE decreased by $60 \%$ (44.2 to $17.6 \mathrm{~kg} \mathrm{DM} / \mathrm{kg} \mathrm{N}$ ) when nitrogen application increased from 50 to $250 \mathrm{~kg} \mathrm{ha}^{-1}$. Moraghebi et al. (2011) reported that by increasing $\mathrm{N}$ application ( 0 to $160 \mathrm{~kg} \mathrm{ha}^{-1}$ of pure $\mathrm{N}$ ), seed yield was increased but NUE and physiological nitrogen efficiency were significantly reduced.

As the law of diminishing returns states that in a production process, as one input variable is increased, there will be a point at which the marginal per unit output will start to decrease, holding all other factors constant, the NUE was not necessarily improved as a result of increased $\mathrm{N}$ application.

\section{Conclusion}

The results of this study showed that, $\mathrm{N}$ and $\mathrm{P}$ fertilizers which were used for wheat production have not reflected the actual needs of wheat. In this experiment, application of $30 \mathrm{t} \mathrm{ha}^{-1}$ of manure under ecoenvironmental scenario caused high availability of $\mathrm{N}$, P nutrients for plant, and improved crop productivity. Moreover, trapped and retained nutrients in manure matrix that is considered as an ecofriendly and low cost input that improved the effectiveness of chemical fertilizer.

Manure applying along with application of $\mathrm{N}$ and $\mathrm{P}$ fertilizers, open new perspectives to develop opportunities for organic fertilizers that could retain crop productivity at same level when chemical fertilizers are applied. Moreover, the use of manure is ecofriendly, low costs and enrich soil fertility. Considering the results, it seems that for the winter wheat production, the eco-environmental scenario had more advantages than other scenarios. Conducting this scenario in long term can be promoting environment health, moreover promises sustainable production of wheat.

\section{Acknowledgements}

Financial support from Ferdowsi University of Mashhad (Grant no. 19800) is gratefully acknowledged. We thank Prof. G. Shahande and Dr. M. Mamarabadi for editing corrections.

\section{References}

Adesemoye, A.O., Torbert, H.A., Klopper, J.W. 2009. Plant growth promoting rhizobacteria allow reduced application rates of chemical fertilizers. Microbial Ecology. 58, 921-929.

Akiyama, H., Tsuruta, H., Watanabe, T. 2000. $\mathrm{N}_{2} \mathrm{O}$ and $\mathrm{NO}$ emission from soils after the application of different chemical fertilizers. Chemosphere Global Change Science. 2, 313-320.

Cassidy, E.S., West, P.C., Gerber, J.S., Foley, J.A. 2013. Redefining agricultural yields: from tones to people nourished per hectare. Environ. Res. Lett. 8, 1-8.

Davis, J.G., Westfall, D.G., Mortvedt, J.J., Shanahan, J.F. 2002. Fertilizing winter wheat. Agronomy Journal. 84, 1198-1203.

Doberman, A., Cassman, K.G. 2004. Environmental dimensions of fertilizer $\mathrm{N}$ : What can be done to increase nitrogen use efficiency and ensure global food security? p. 261-278. In: A.R. Mosier et al. (ed.) Agriculture and the nitrogen cycle: assessing the impacts of fertilizer use on food production and the environment. SCOPE 65. Island Press, Washington, D.C.

Doberman, A., Cassman, K.G. 2005. Cereal area, yield and nitrogen use efficiency and drives for future nitrogen fertilizer consumption. Science in China. 48, 745-758. 
Dordas, C.A. 2011. Nitrogen nutrition index and its relationship to $\mathrm{N}$ use efficiency in linseed. Europ. J. Agronomy. 34, 124-132.

Emilsson, T., Brendtsson, J.C., Mattsson, J.E., Rolf, K. 2007. Effect of using conventional and controlled release fertilizer on nutrient runoff from various vegetated roof systems. Ecological Engineering. 29, 260-271.

Fageria, N.K. 2014. Nitrogen Management in Crop Production. New York: CRC Press.

FAO Country Profiles for IRAN. 2014.

FAO Statistical Yearbook: World Food and Agriculture. 2013.

FAO. 2012. The State of Food and Agriculture 2012 Investing in Agriculture for a Better Future, FAO, Rome, Italy.

Gastal, F., Lemaire, G. 2002. N uptake and distribution in crops: an agronomical and ecophysiological perspective. Journal of Experimental Botany. 53, 789-799.

Gliessman, S.R. 1998. Agroecology: Ecological Processes in Sustainable Agriculture. CRC Press.

Hatfield, J.L., Prueger, J.H. 2004. Nitrogen over-use, under-use, and efficiency. Crop Science. 26, 156168.

Hawkesford, M.J., Barraclough, P. 2011. The Basis of Nutrient Use Efficiency in Crops. WILEYBLACKWELL, USA. ISBN: 978-0-8138-1992-1.

Horwitz, W., Latimer, G.W. 2005. Official Methods of Analysis. Association of Official Analytical Chemists (AOAC), 18 ${ }^{\text {th }}$ Edition. Maryland, USA.

Hussain, Z., Khattak, R.A., Irshad, M., Mahmood, Q., An, P. 2016. Effect of saline irrigation water on the leachability of salts, growth and chemical composition of wheat (Triticum aestivum L.) in saline-sodic soil supplemented with phosphorus and potassium. Journal of Soil Science and Plant Nutrition. 16, 604-620.
Jarvis, S., Hutchings, N. Brentrup, F. Olesen, J.E., Van Der Hock, K.W. 2011. Nitrogen flows in farming systems across Europe. In: Sutton, M.A., Howard, C.M. Erisman, J.W. Billen, G. Bleeker, G. Grennfelt, A. Grinsven, H.V. and Grizzetti, B. (Eds.) The European Nitrogen Assessment: source, effects and policy perspectives 2011. Cambridge University Press. Part III, Chapter 10.

Kramer, P. 1988. Measurement of plant water status: Historical perspectives and current concerns. Irrigation Science. 9, 275-287.

Mahmood, F., Khan, I., Ashraf, U., Shahzad, T., Hussain, S., Shahid, M., Abid, M., Ullah, S. 2017. Effects of organic and inorganic manures on maize and their residual impact on soil physico-chemical properties. Journal of Soil Science and Plant Nutrition. 17, 22-32.

Marino, M.A., Mazzanti, A., Assuero, S.G., Gastal, F., Echeverria, H.E., Andrade, F. 2004. Nitrogen dilution curves and nitrogen use efficiency during winter-spring growth of annual ryegrass. Agronomy Journal. 96, 601-607.

Martinez-Lagos, J., Salazar, F., Alfaro, M., Rosas, M., Macias, F. 2015. Nitrogen mineralization in a silandic andosol fertilized with dairy slurry and urea. Journal of Soil Science and Plant Nutrition. $15,60-75$.

Mengel, K., Kirkby, E.H. 2001. Principles of plant nutrition. Kluwer Academic Publishers, Boston. 849pp.

Moraghebi, F., Akbari, M., Hooshmanfar, A. 2011. The effects of amount and time of nitrogen application on seed protein content and nitrogen use efficiency of wheat under Saveh conditions. Quarterly of Plant and Ecosystem. 7, 65-76.

Myers, R.H., Montgomery, D.C. 1995. Response surface methodology: process and product optimization using designed experiments. John Willey \& Sons, New York, USA. 
Osborne, S.L. 2007. Utilization of existing technology to evaluate spring wheat growth and nitrogen nutrition in South Dakota. Communication in Soil Science and Plant Analysis. 38, 949-958.

Rathke, G.W., Behrens, T., Diepenbrock, W. 2006. Integrated nitrogen management strategies to improve seed yield, oil content and nitrogen efficiency of winter oilseed rape (Brassica napus L.): A review. Agriculture, Ecosystems and Environment. 117, 80-108.

Sandaña, P., Pinochet, D. 2016. Phosphorus acquisition of wheat, pea and narrow-leafed lupin under different P supplies. Journal of Soil Science and Plant Nutrition. 16, 537-549.

Schlemmer, M.R., Francis, D.D., Shanahan, J.F., Schepers, J.S. 2005. Remotely measuring chlorophyll content in corn leaves with differing nitrogen levels and relative water content. Agronomy Journal. 97, 106-112.

Seguel, A., Castillo, C.G., Morales, A., Campos, P., Corenjo, P., Borie, F. 2016. Arbuscular Mycorrhizal symbiosis in four Al-tolerant wheat genotypes grown in an acidic Andisol. Journal of Soil Science and Plant Nutrition. 16, 164-173.
Shah, G.M., Shah, G.A., Groot, J.C.J., Raza, M.A.S., Shahid, N., Lantinga, E.A. 2016. Maize nitrogen recovery and dry matter production as affected by application of solid cattle manure subjected to various storage conditions. Journal of Soil Science and Plant Nutrition. 16, 591-603.

Sparling, G.P., Wheeler, D., Vesely, E.T., Schipper, L.A. 2006. What is soil organic matter worth? Journal of Environmental Quality. 35, 548-557.

Saleh, T.A., Sari, A., Tuzen, M. 2017. Optimization of parameters with experimental design for the adsorption of mercury using polyethylenimine modified-activated carbon. Journal of Environmental Chemical Engineering. 5, 1079-1088.

Weligama, C., Sale, P.W.G., Conyers, M.K., Liu, D.L., Tang, C. 2010. Nitrate leaching stimulates subsurface root growth of wheat and increase rhizosphere alkalization in a highly acidic soil. Plant and Soil. 328, 119-132. 